\title{
Impact of Bacterial Contamination on Blood Supply
}

\author{
Gabriele Walther-Wenke ${ }^{\mathrm{a}}$ Michael Schmidt ${ }^{\mathrm{b}}$ \\ a Centre for Transfusion Medicine, German Red Cross Blood Donation Service West, Münster, \\ ${ }^{b}$ German Red Cross, Institute for Transfusion Medicine and Immunohaematology, Johann Wolfgang Goethe University, \\ Frankfurt/M., Germany
}

Bacterial contamination of blood components is a long-standing problem affecting the safety of blood supply. Transfusiontransmitted syphilis was the first recognized bacterial infection transmitted by blood transfusions via vascular anastomosis, first described in 1915 and successfully eliminated mainly by reducing the frequency of infection and by donor screening [1]. The first fatality due to whole blood transfusion was reported in 1942 [2].

In the past decades remarkable advances could be achieved in all fields of work in blood establishments that improved quality and safety of blood components. Most efforts were concentrated on minimizing the risk of transfusion-transmitted virus infections. Meanwhile the residual bacterial risk for transfusion-transmitted infections has become the most frequent infection risk in transfusion medicine.

In the past 15 years many studies focused on the challenge of bacterial contaminations, especially of platelet concentrates (PCs). Numerous measures were implemented to reduce the initial contamination of blood at the time of collection and to reduce bacteria proliferation during processing and storage of blood components. The cumulative effect of these measures led to a significant improvement, but hemovigilance systems internationally still report cases of serious morbidity and mortality due to bacterial contaminations [3-5].

As reported in hemovigilance systems the risks of bacterial contamination of platelets are currently the major infection risk. Low numbers of bacteria may initially contaminate PCs, but storage at $22{ }^{\circ} \mathrm{C}$ for several days allows growth followed by high bacterial loads at the time of transfusion. Culturebased pre-release screening of PCs with early sampling has proven to detect bacteria and to prevent transfusion of some but not all contaminated units. In a study of one million apheresis PCs the rate of septic reactions decreased from 18 to 5.4 reactions per million transfused units, but the fatality rate did not decrease [6]. Fatalities were not associated with bacteria typical for skin flora but with Gram-negative rods, mainly Enterobacteriaceae. The risk of severe and fatal reactions, particularly with these more virulent contaminants, is therefore likely to remain. Most studies on results of prerelease screening of platelets with early sampling (within $24 \mathrm{~h}$ after blood donation) reported septic reactions due to falsenegative cultures. Based on the reported data it can be suggested that bacterial culture may fail to detect more than half of the contaminated products [7]. As risk of severe reactions increases with the age of PCs, the Advisory Board of the German Ministry of Health decided in 2008 to reduced the maximum shelf life for PCs from 5 days after donation to 4 days [8].

Rapid detection methods with a late sample collection (day 3 , day 4 or day 5 after donation) are suitable for testing platelets for bacteria prior to issue for transfusion. Some tests are already available, others are in development; but much work remains to optimize tests for routine use and to find out when they give most useful results.

As French hemovigilance data show, bacterial contamination of red blood cell (RBC) concentrates accounts for $10 \%$ or less of severe septic reactions; measures implemented to improve bacterial safety reduced the frequency of transfusion reactions caused by contaminated RBC concentrates [9]. In Germany the absolute number of reported septic reactions associated with transfusion of RBC concentrates and PCs in the observation period $1997-2008$ is in the same range, with 34-38 reports [5]. In that time frame, 20.6 million RBC concentrates and 4.2 million PCs were transfused. Thus the ideal strategy to improve bacterial safety should include all blood components.

Pathogen inactivation, an approach that purposes a fundamentally different and far more ambitious objective, focuses on viruses, parasites, leukocytes and bacteria as contaminants of blood components. Inactivation techniques that optimally preserve the biological function of constituents and are harmless to the recipient are under evaluation for their efficacy and

\section{KARGER}

Fax +497614520714

Information@Karger.de

www.karger.com (c) 2011 S. Karger GmbH, Freiburg

Accessible online at:

www.karger.com/tmh
Dr. med. Gabriele Walther-Wenke

DRK-Blutspendedienst West

Zentrum für Transfusionsmedizin

Sperlichstraße 15, 48151 Münster, Germany

Tel. +49 251 709-209, Fax -119

g.walther-wenke@bsdwest.de 
safety. They promise to be a solution for the difficult problem of bacterial contamination in the future.

The current issue of Transfusion Medicine and HemoTHERAPY is focused on impact of bacterial contamination on blood supply.

Walther-Wenke et al. [10] present data on bacterial contamination rates of blood components that origin from routine quality control investigations in German blood establishments. Data out of three surveys between 1998 and 2006 show a remarkable decline in bacterial contamination rates of all blood components as a result of safety measures implemented in donation and manufacturing processes.

McDonald [11] focuses on interventions such as improved donor arm disinfection and diversion of the initial blood flow and describes their impact on the bacterial contamination rate. Data from a National Health Service Blood and Transplant study indicate a reduction of the bacterial contamination rate of blood components by about $70 \%$.

Funk et al. [12] report German hemovigilance data on transfusion-transmitted bacteria infections that were collected from 1997 to 2010, and analyze the incidence of transfusiontransmitted bacteria infections before and after implementation of risk-reducing measures.

Gatermann [13] describes bacteria species known as contaminants of blood components with respect to their pathogenicity.

Schmidt et al. [14] present an overview of bacterial detection methods which can be clustered into three groups: cul- ture methods in combination with the 'negative-to-date' concept, rapid detection systems with a late sampling and bedside screening tests. Each system exhibits advantages and disadvantages and offers only a temporary solution until a general pathogen inactivation technology is available for all blood components.

de Korte [15] describes the Dutch experience with 10 years bacterial screening of platelets with the BacT/ALERT culturing system using a high inoculation volume and release of products on a 'negative-to- date' basis. In the Netherlands platelets have a maximum shelf life of 7 days since 2002. The author states, that the number of transfusion-transmitted bacterial infections currently is very low.

Borosak and Wood [16] give a report about the Australian experience where bacterial screening of platelets was implemented in April 2008. Authors state that screening of platelets is an important improvement in transfusion safety.

Müller et al. [17] describe the specific threats of bacteria as contaminants of blood components and their impact on the assessment of the effectiveness of pathogen reduction procedures. Studies were done with internationally accepted bacterial standards, developed by the Paul-Ehrlich-Institute, which enable a better comparison with different study designs.

All together this issue of Transfusion Medicine And HemotherAPy provides an overview on different aspects of bacterial contaminations of blood components and challenges, issues and difficulties to improve blood safety.

\section{References}

1 Orton S: Syphilis and blood donors: what we know, what we do not know, and what we need to know. Transfus Med Rev 2001;41:1069-1071.

2 Officer R: Blood storage on active service. Aust N Z J Surg 1942;12:111-118.

3 Agence Francaise de Sécurité Sanitaire des Produits de Santé. French international report. Available at: www.afssaps. fr/Activites/Hemovigilance.

4 Taylor C, Cohen H, Mold D, Jones H, et al: The 2009 annual SHOT report (2010). Available at www.shotuk.org.

5 Funk MB, Günay S, Lohmann A, Witzenhausen C, Henseler O. Hämovigilanz-Bericht 1997 bis 2008 . Available at: $w w w$.pei.de/hv-bericht.

6 Eder AF, Kennedy JM, Dy BA, et al: Bacterial screening of apheresis platets and the residual risk of septic transfusion reactions: the American Red Cross experience (2004-2006). Transfusion 2007;47:1134-1142.

7 Benjamin RJ: Bacterial culture of apheresis platelet products and the residual risk of sepsis. ISBT Science Series 2008;3:133-138.
8 Arbeitskreis Blut: Festlegung der Haltbarkeitsfrist von Thrombozytenkonzentraten mit dem Ziel der Reduktion lebensbedrohlicher septischer Transfusionsreaktionen durch bakterielle Kontamination. 66. Sitzung des Arbeitskreises Blut am 09.06,2008. Bundesgesundheitsbl Gesundheitsforsch Gesundheitsschutz 2008;51:1484.

9 Andreu G, Caldani C, Morel P: Reduction of septic transfusion reactions related to bacteria contamination without implementing bacteria detection. ISBT Science Series 2008;3:124-132.

10 Walther-Wenke G, Däubener W, Heiden M, Hoch J, Hornei B, Volkers PWirsing von König C-H; Working Party on Bacteria Safety in Transfusion Medicine of the National Advisory Committee Blood of the German Federal Ministry of Health (Arbeitskreis Blut), Berlin, Germany: Bacterial Contamination Rates of Blood Components in Germany: Results of Culture-Based Testing as Part of Routine Quality Control. Transfus Med Hemother 2011;38(4):231-235.

11 McDonald C: Interventions implemented to reduce the risk of transmission of bacteria by transfusion in the English National Blood Service. Transfus Med Hemother 2011;38(4):255-258.
12 Funk MB, Lohmann A, Guenay S, Henseler O, Heiden M, Hanschmann KMO, Keller-Stanislawski B: Transfusion Transmitted Bacterial Infections (TTBI) - Haemovigilance Data of German Blood Establishments (1997-2010). Transfus Med Hemother 2011;38(4):266-271.

13 Gatermann SG: Pathogenicity of Bacteria Contaminating Blood Products. Transfus Med Hemother 2011;38(4):236-238.

14 Schmidt M, Sireis W, Seifried E: Implementation of Bacterial Detection Methods into Blood Donor Screening - Overview of Different Technologies. Transfus Med Hemother 2011;38(4):259-265.

15 de Korte D: 10 Years Experience with Bacterial Screening of Platelet Concentrates in the Netherlands. Transfus Med Hemother 2011;38(4):251-254.

16 Borosak ME, Woods EM: Bacterial Pre-Release Testing of Platelets: The Australian Red Cross Blood Service Clinical Experience. Transfus Med Hemother 2011;38(4):239-241.

17 Müller TH, Montag T, Seltsam AW: Laboratory evaluation of the effectiveness of pathogen reduction procedures for bacteria. Transfus Med Hemother 2011;38(4):242-250. 